\title{
STUDENTS’ PERCEPTION OF MEDICAL PROFESSIONALISM
}

\author{
Cicih Bhakti Purnamasari*1, Fairuz Salsabila Faisal ${ }^{1}$ \\ ${ }^{1}$ Dentistry Study Programme, Mulawarman University, Indonesia \\ *E-mail : c.purnamasari@fk.unmul.ac.id
}

\begin{abstract}
Mastery of professionalism is a necessity in medical education. However, the application in education is still limited. Therefore, it is necessary to explore the definition of professionalism in the medical field. This study aimed to explore students' perceptions of medical professionalism, as well as the behavioral components that demonstrate professionalism. This was a qualitative analytic study, carried out among 2 focus group discussions (FGD) of students with a grounded theory approach in data analysis. The research was conducted at the Faculty of Medicine, Gadjah Mada University. Results showed that students' perceptions of medical professionalism included mastery of knowledge, skills, and overall attitudes. Meanwhile, the professionalism component consists of altruism, competence, honesty and integrity, performance, management, respect for others and humanism.
\end{abstract}

Keywords: professionalism, medical professionalism

\section{INTRODUCTION}

The medical profession has been long known as one of the oldest professions. ${ }^{1}$ As other humanrelated professions are regarded as the subject and object of the profession, the medical field has characteristics that become the reference of assessment or achievement, and it is avowed as professionalism. ${ }^{2,3,4}$ Professionalism in the medical field is closely related to the social contract between professional practitioners, in this case, healthcare workers with the community. However, most of these social contracts are only in a form of unwritten agreement. ${ }^{5}$ Meanwhile, the expected standard of achievement is an optimal service. ${ }^{2,6,7}$ Therefore, an understanding of the medical professionalism of healthcare workers is important. This understanding is expected to become the basis for determining the action, as well as establishing the program and policies related to further medical development.

Literature and research that aim to explore and understand medical professionalism have

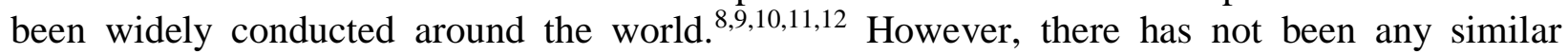
research conducted in Indonesia. As previously stated, medical professionalism is closely related to the surrounding community as the subject and object of interaction. Indonesian has different characteristics from western culture. ${ }^{13,14,15}$ The differences in characteristics could differently influence the interaction and understanding of medical professionalism.

Research on medical professionalism had been conducted by Rahayu et al. involving several religious leaders, ethics and moral experts as respondents. ${ }^{16}$ The research resulted in 5 attributes of professionalism consisting of respect, honesty, integrity, responsibility, altruism, and attributes of faith that characterizes Indonesia. Meanwhile, research that aims to understand the educators and students' points of view and perceptions of students as subjects and objects of medical learning has never been conducted. Based on these considerations, this research seeks to 
Received : 2020-12-13 Revised : 2021-05-24 Acceptance : 2021-06-08 Publish : 2021-06-17 gain a basic understanding of medical professionalism, particularly in Indonesia, from the students' perspectives. The student-centered paradigm puts students as subjects as well as consumers in teaching and learning activities. ${ }^{17}$ Their participation in the learning process is one of the factors to ensure and improve the quality of learning itself. ${ }^{18}$ The researcher also intends to examine the behavioral components so it could be regarded as the professional doctors' behavior, especially concerning the needs of healthcare workers/doctors in Indonesia.

\section{MATERIAL AND METHOD}

This was qualitative analytical research that uses a grounded theory approach to analyze the data following the exploratory objectives of the study. ${ }^{19,20}$ In qualitative research, the researcher becomes the research instrument. However, to minimize bias and improve the quality of data collection, the researcher was assisted by an independent anthropologist as an interviewer and peer coder during the triangulation process. ${ }^{19,21}$

The selection of respondents was based on the criterion-based method combined with the maximum variation sampling, to ensure the selection of respondents was following the research objectives and represents a variation of several groups. ${ }^{22}$ Respondents were divided into 2 FGD groups and selected from each batch year, both undergraduate and professional strata. The inclusion criteria for respondents were that they do not have any bad record from the faculty ethics committee and have a GPA of $\geq 3.50$ on a 4.0 scale. There were 6 undergraduate students and 4 professional students. Each group conducts 2 discussions and 1 meeting for member checking. Each stage of the FGD was manually noted and its audio and video were also recorded. The results of the recording were transcribed by an independent and official transcription institution which followed by comparatively analyzed by the researcher and peer. Those steps were done to maintain the validity and reliability of the research data. The collected data was analyzed as follows:

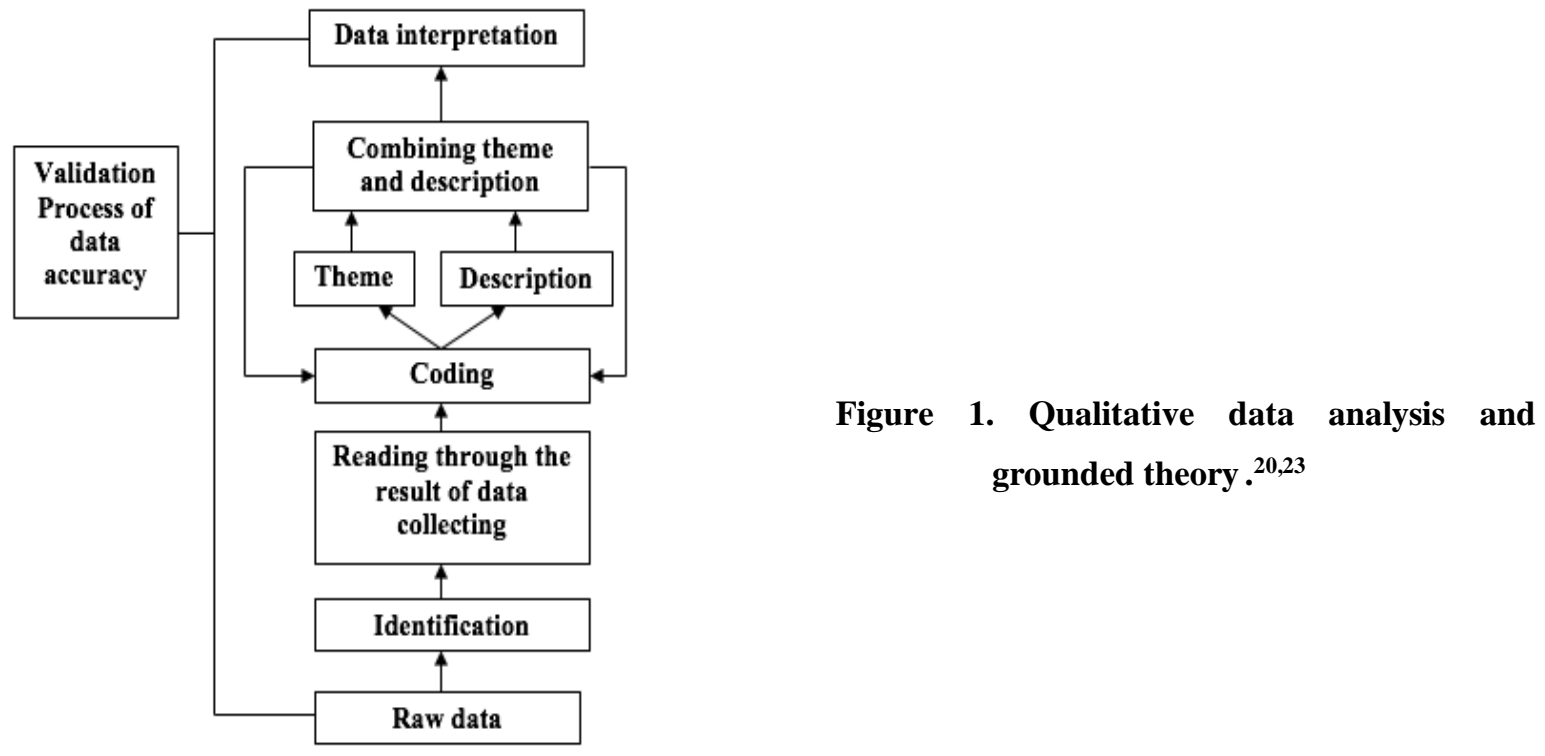

Data was analysed uses a grounded theory approach with open-axial coding and constant comparability. The results are obtained from the research data by taking back and forth steps to ensure the results in the next step are related and are the result of the previous step. ${ }^{20}$ 
Received : 2020-12-13 Revised : 2021-05-24 Acceptance : 2021-06-08 Publish : 2021-06-17 Triangulation through member checking the FGD participants, as well as multiple coders, is carried out to increase the internal validity of this research. The respondent selection method also increases the credibility and reliability of the research. ${ }^{24,25}$

\section{RESULTS AND DISCUSSION}

Respondents provide an understanding of medical professionalism that mastery of knowledge, skills, and attitudes as a whole are the main requirements of a professional. Furthermore, there were six components of professional behavior that become the indicator of professionalism as a doctor: altruism, competence, honesty, integrity, management, respect for others, and humanism. The ability to adapt to culture (cultural sensitivity) was an important part of medical professionalism in the Indonesian context. However, this aspect did not represent a whole component, but rather a part of the humanism component. Medical professionalism was expressed as a set of behavioral attitudes and mindsets as a form of mastery of competencies based on the code of ethics and regulations.

“...in my opinion, professionalism itself means behavior that reflects, I mean, it's called a profession so it reflects the profession itself. The point is to do what is right and necessary thereby building trust." (Dl)

“...behavior, an attitude whose term is suitable with other people's expectations of one's profession”. (D)

Respondents emphasize professionalism as the behavior in taking action. The establishment of behavior is also influenced by the attitudes, values, and norms that are believed. ${ }^{26,27}$ Attitudes were expressed as a possibility or tendency of a person to act or react to an object or event, either positively or negatively. ${ }^{27}$ Attitude was formed due to desire and information obtained. ${ }^{28}$ Therefore, ideal information and understanding will influence the establishment of an ideal attitude as well. As later concluded by van Luijk, ${ }^{29}$ the essence of medical professionalism is a combination of personal values and standards with an attitude shown in observable everyday behavior.

The observable behavior was a form of actualization of one's attitude, knowledge, and skills that they implement in the medical profession. These three qualities have interconnectedness that influences one another and become a part of oneself. Therefore, in every decision and action as well as treatment, a professional doctor could establish specific considerations as a result of the three aforementioned qualities.

"...for doctors, the first one is clear. The first is knowledge. It's impossible for a doctor who is not competent to work in the community. And also their communication skill when it comes to communicating with one another, and procedural skill " $(\mathrm{N})$

The behavioral component becomes an indicator of medical professionalism as it can be observed and assessed by patients or other people. ${ }^{29}$ The behavioral component in this study becomes an important requirement in the professional doctor-patient relationship. This correlates with the direct consequences of the medical profession, in which the nature of the profession is associated with humanity. ${ }^{30}$ Some authors have called this relationship a social contract between 
Received : 2020-12-13 Revised : 2021-05-24 Acceptance : 2021-06-08 Publish : 2021-06-17 the medical profession/doctor and the community, and behavior becomes the key to bridging this relationship. ${ }^{31}$

There were several characteristics of the behavioral components that are specifically found in this study. These characteristics emerge as a result of individual factors in forming perceptions. ${ }^{32,33}$ The first characteristic is related to belief and dogma. Respondents stated that religion is an important part of professionalism as a concequence of values of professionalism and good deeds in the religious teachings and the holy book. Previous research has also found the characteristics of religion in medical professionalism, particularly in Indonesia, which states that religion is one of the components of professionalism and is termed as faith. ${ }^{16}$ The result of this study provides a different picture and view on the characteristics of religion in the professionalism of doctors. The characteristics of religion in this study put more emphasis on the embedded religious teachings, such as humanism and respect for others as well as individual traits and performance, rather than dogma nor divinity. Therefore, religion is not a behavioral component of medical professionalism, but it is a background that contributes to the establishment of professionalism. Table 1 shows the instructors and students' perceptions of the components of professional behavior. Research respondents provided statements, understandings, and examples of behavioral components which are then grouped into 6 behavioral components of medical professionalism: (1) altruism, (2) competence, (3) honesty and integrity, (4) performance, (5) management, and (6) respect for others and humanism. On a broader scale, the two groups of respondents have relatively similar understanding and perspectives. Instructors provide examples from their service experiences, while students provide examples as observers and from the experience of others.

Table 1. The component of professional behavior according to students

\begin{tabular}{|c|c|}
\hline Behavioral Component & Students' Quotation \\
\hline Altruism & $\begin{array}{l}\text { "...doctor's attitude in treating the patient means even if the doctor } \\
\text { is tired or something, the patient is still treated well..." }\end{array}$ \\
\hline Competence & $\begin{array}{l}\text { "...for example, they prescribe this medicine, why were they given } \\
\text { the medicine or maybe why they weren't?..." }\end{array}$ \\
\hline Honesty and Integrity & $\begin{array}{l}\text { "for prescription, we used more generic medicine rather than the } \\
\text { branded one, for example..." }\end{array}$ \\
\hline Performance & $\begin{array}{l}\text { "...for example, if a doctor wears their coat, then they will wear it } \\
\text { at the right time..." }\end{array}$ \\
\hline Management & $\begin{array}{l}\text { "...they don't do weird things, are objective with patients, } \\
\text { understand their patients, and find a balance between career and } \\
\text { family..." }\end{array}$ \\
\hline $\begin{array}{l}\text { Respect for others and } \\
\text { Humanism }\end{array}$ & $\begin{array}{l}\text { "...in everyday life, everyone that we meet must be treated with } \\
\text { respect, we mustn't do something arbitrarily, talking to ourselves, } \\
\text { and must be honest when it comes to helping them..." }\end{array}$ \\
\hline
\end{tabular}

Altruism in medicine was defined as a behavior that prioritizes patient needs over other considerations. ${ }^{7}$ This correlates with the nature of the profession and its interactions with 
Received : 2020-12-13 Revised : 2021-05-24 Acceptance : 2021-06-08 Publish : 2021-06-17 humans. In its implementation, this behavior correlates with the individual's ability in establishing specific considerations.

Competence was defined as the ability of a doctor in terms of knowledge and skills. Every action taken is based on up-to-date and evidence-based knowledge. ${ }^{7}$ This ability ultimately supports the best decision taken and a balance between cognitive, psychomotor, and affective capability. Honesty and integrity are also part of the component of professional behavior. One way to show integrity is through an honest attitude and behavior based on rules and moral values. $^{4}$

The next component of behavior is performance. This component correlates to physical appearance, body language, and psychology, namely traits that need to be exhibited by a doctor. Self-control is also included in this behavioral component.

"...we are taught not to confront the culture, but to find ways to accommodate it without disturbing or causing health problems..." (Mk)

Furthermore, communication skills are important in the implementation of medical professionalism. Professional doctors were defined as doctors who have a good mastery of communication, for instance, during the exploration of complaints such as anamnesis, and other parts of therapeutic communication.

"...knowing how to socialize in cultural communities. Knowledge in communication is very important, perhaps also equipped with the knowledge in psychology" (Tr).

Management in medical professionalism correlates with the ability to do priority scale and handle problems during an emergency. ${ }^{34}$ The last component of behavior is humanism and respect for others. This component is closely related to altruistic behavior. However, in this group of behavior, there is more emphasis on broader human values as well as things for establishing good relationships. ${ }^{7}$

Habits, cultures, moral values, and virtuous values in religion greatly influence the selection and establishment of the component of professionalism. Religion and moral values in the community are some of the indicators to behave professionally. This correlates to the values of kindness and humanity that are being taught within a religion. Furthermore, there are characteristics of professionalism found in this study. This correlates to manners and customs in the community. Respondents of the research stated that the ability of healthcare workers to adapt to culture (cultural sensitivity), habits, and local conditions are very important. Every culture and local value are principally guided by the same human values, however, how they are conveyed can be different in each region. On the other hand, a doctor is expected to be able to optimally execute their job as stated in their social contract. ${ }^{4,5}$

"...I studied this because of a proverb. I'm interested in the proverb that said "when in Rome, do as the Romans". Learning is important. We must be able to follow local wisdom..."(S) 
Received : 2020-12-13 Revised : 2021-05-24 Acceptance : 2021-06-08 Publish : 2021-06-17

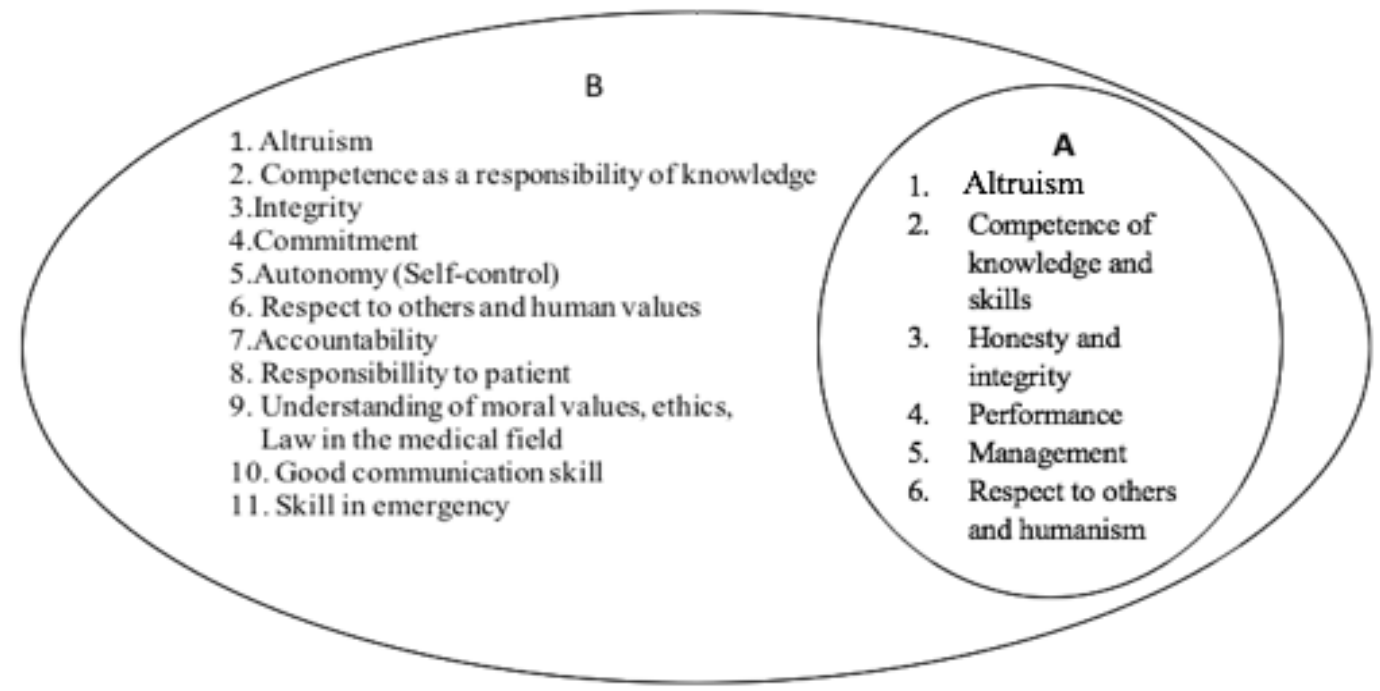

Figure 2. Correlation between the behavioral component of professionalism from the result of the research (A), and the universal component of behavior (B)

Similar to what has previously stated, research and literature review on professionalism have been widely carried out around the world, thereby there is a universal component of behavior. Figure 2 shows the correlation between the universal component of professional behavior and the component of behavior found in this study. Overall, the component of professionalism behavior in this research falls into the universal component of professionalism. Therefore, it can be stated that the universal component of behavior can be adopted in the process of developing medical professional behavior in Indonesia. However, in its implementation, it is necessary to emphasize an understanding of regional culture and its adaptability. The implementation of this research has a relative perspective, related to the culture and the local habits in the research setting. ${ }^{25}$ The research limitation is due to the large number of cultures in Indonesia that have not been explored.

\section{CONCLUSION}

Based on the research discussion, it can be concluded that students' understanding of medical professionalism covers mastery of knowledge, skills, and attitude which give them the ability to establish specific considerations. There are six components of professionalism behavior: altruism, competence, honesty and integrity, performance, management, humanism, and respect for others. One of the important things that need to be emphasized in mastering medical professionalism is cultural sensitivity. However, this aspect does not form a new component because it essentially can be grouped under the humanist component.

Further researchers are suggested to conduct a deeper analysis of the correlation between professionalism and the diverse cultures in Indonesia. Moreover, the universal component of behavior can be adopted directly in the process of developing medical professionalism in Indonesia by paying attention to the adaptability of local cultures. 
Received : 2020-12-13 Revised : 2021-05-24 Acceptance : 2021-06-08 Publish : 2021-06-17

\section{REFERENCES}

1. Magner, L.N. 2005. A History of Medicine, $2^{\text {nd }}$ edition. Boca Raton: Taylor \& Francis Group.

2. Miles, M.B., dn Huberman, A.M. 1994. An Expanded Source Book: Qualitative Data Analysis. California: Sage Publications.

3. Flexner, A. 1915. Is Social Work a Profession?. New York: Cornell University Library

4. Sohl, P. dan Bassford, H.A. 1986. "Codes of Medical Ethics: Traditional Foundations and Contemporary Practice”. Soc. Sci. Med. 22 (11), page: 1175-1179.

5. Cruess, S.R. dan Cruess, R.L. 2009. The Cognitive Base of Professionalism. di dalam Cruess, R.L. et al. eds. Teaching Medical Professionalism. New York: Cambridge University Press.

6. Cruess, R. L., Cruess, S.R., dan Johnston, S.E. 2000. "Professionalism: An Ideal To Be Sustained". Lancet, 356, halaman: 156-59.

7. American Board of Internal Medicine 2001. Project Professionalism. Philadelphia: ABIM

8. Wright, G.B. 2011. Student-centered learning in higher education in International Journal of Teaching and Learning in Higher Education. Vol 23 (3). 92-97

9. Epstein, R.M. dan Hundert, E.M. 2002. "Defining and Assessing Professional Competence". Journal of the American Medical Association, 287(2), halaman : 226-35.

10. Jha, V., Bekker, H.L., Duffy, S.R.G. \& Roberts, T.E. 2006. "Perceptions of Professionalism in Medicine: A Qualitative Study". Medical education, 40, halaman: 1027-1036.

11. Wagner, P., Julia, H., Mosseley, G. dan Hudson, V. 2007. "Defining Medical Professionalism: A Qualitative Study". Medical Education, 41, halaman : 288-294.

12. Green, M., Zick, A dan Makoul, G. 2009. "Defining Professionalism from The Perspective of Patients, Physicians and Nurses". Academic Medicine, 84, halaman: 566573.

13. 12. Aguilar, A.E., Stupans, L. dan Scutter, S. 2011 "Assessing Students' Professionalism : Considering Professionalism's Diverging Definitions”. Education for Health, 24 (3). Diunduh dari www.educationforhealth.net

14. Mangunsarkoro, S. 1951. Kebudajaan Rakjat. Yogyakarta: Usaha Penerbita Indonesia.

15. Claramita, M., et. al. 2012. "Doctor-Patient Communication in Southeast Asia: A Different Culture?". Health Sci Educ DOI 10.1007/s10459-012-9352-5.

16. Dewantara, K.H. 2013. Pemikiran, Konsepsi Keteladanan, Sikap Merdeka. Yogyakarta: UST Press.

17. Rahayu, G.R., et. al. 2011. "Pengembangan Model Perkembangan Profesionalisme Dokter". Laporan Akhir Hasil Penelitian Hibah Tim Pascasarjana tahun anggaran 2011. Universitas Gadjah Mada.

18. Rudland, J.R. 2009. Learning in small groups. Di dalam Dent, A.D dan Harden, R.M. eds. A practical guide for medical teachers. London: Elsevier. pp, $80-85$.

19. WHO. (2010) Regional guidelines and instruments for institutional quality assurance in medical education. India: WHO Regional Office for South-East Asia.

20. Sugiyono. 2011. Metode Penelitian Kuantitatif, Kualitatif dan $R$ \& D. Bandung; Alfabeta.

21. Watling, C.J., dan Lingard, L. 2012. "Grounded Theory" in Medical Education Research: AMEE Guide No. 70. Medical Teacher, e1-e12. 
Received : 2020-12-13 Revised : 2021-05-24 Acceptance : 2021-06-08 Publish : 2021-06-17

22. Oppenheim, A.N. 2001. Questionnaire Design, Interviewing and Attitude Measurement. London : Biddles Ltd.

23. Idrus, M. 2009. Metode Penelitian Ilmu Sosial. Pendekatan Kualitatif dan Kuantitatif edisi kedua. Jakarta : Erlangga.

24. Creswell, J.W. 2009. Research Design. Qualitative, Quantitative and Mix-methods Approaches $3^{\text {rd }}$ edition. Thousand Oaks: Sage Publication Inc.

25. Miles, M.B., dn Huberman, A.M. 1994. An expanded sourcebook: Qualitative data analysis. California : Sage Publications.

26. Barbour, R., S. 2001. "Checklists for Improving Rigour in Qualitative Research: A Case of The Tail Wagging The Dog?". BMJ; 322, halaman: 1115-1117.

27. Health and Safety Executive (HSE). 2009. "Reducing Error and Influencing Behaviour". Surrey: HSE Books. Diunduh dari www.hse.gov.uk

28. Archer, R., et. al. 2008. "The Theory of Planned Behaviour in Medical Education: A Model for Integrating Professionalism Training”. Medical Education, 42, halaman: 771777.

29. Mar'at, S., dan Kartono, L.I. 2006. Perilaku Manusia. Ed Polhaupessy : Bandung.

30. van Luijk, S.J. ed. 2005. Professional Behaviour. Teaching, Assessing and Coaching Students. Maastricht : Universitaire Pers Maastricht.

31. Arnold, L. dan Stern, D.T. 2006. "What is Medical Professionalism?”. Di dalam Stern, D.T. ed. Measuring Medical Professionalism. Oxford: Oxford University Press, halaman: $15-37$.

32. Cruess, S.R. dan Cruess, R.L. 2009. The cognitive base of professionalism. di dalam Cruess, R.L. et al. eds. Teaching medical professionalism. New York: Cambridge University Press.

33. Wade, C. dan Tavris, C. 2007. Psychology $9^{\text {th }}$ ed. Diterjemahkan oleh Widyasinta, B dan Juwono, I.D. Jakarta : Erlangga.

34. Robbins, S.P dan Judge, T.A 2010. Organizational behaviour $12^{\text {th }}$ ed. Diterjemahkan oleh Angelica, D. Cahyani, R. dan Rosyid, A. Jakarta : Salemba Empat.

35. Tromp, F., Rademakers, J.J.D.J.M. dan Ten Cate, T.J..2007. Development of an instrument to assess professional behavior of foreign medical graduates. Medical Teacher, 29, pp. 150-155. 